\title{
A MEGASECOPTERON FROM UPPER CARBONIFEROUS STRATA IN SPAIN ${ }^{1}$
}

\author{
By F. M. Carpenter \\ Harvard University
}

In 1962 Professor F. Stockmans, of the Institut Royal des Sciences Naturelles de Belgique, kindly sent me for study two insects from Upper Carboniferous deposits in Northern Spain. One of these (no. 94.837), from the Mine de Poleiro, is part of a cockroach tegmen, which cannot be placed with certainty even to family level. The other specimen (no. 97.587), from shales near the village of Magdalena, is a nearly complete, well-preserved wing of a megasecopterous insect. Since it shows interesting venational features and since there seems little chance of obtaining additional insects from this deposit in the near future, I have considered it advisable to publish a formal description of the fossil at this time. I am indebted to Dr. Stockmans not only for his courtesy in loaning me these specimens but for providing me with information about the geology and stratigraphy of the formation concerned.

\section{Family Anchineuridae, new family}

Differing from all other known families of Megasecoptera by having the cross veins numerous, irregular, and equally distributed over the wing area. The subcosta runs very close to the costal margin, terminating in the distal area of the wing; the costal margin is somewhat thickened and in the distal quarter of the wing, before the apex, the thickened area becomes much broader; the radius is parallel with the subcosta and close to it but not so near as Sc is to the costal margin. The radial sector has numerous branches, MA is free from Rs, and $\mathrm{CuA}$ is free from MP. The costal margin of the wing bears numerous, conspicuous, stout setae, especially prominent in the thickened region of the costa; the rest of the wing margin from the apical region along the posterior margin to the wing base bears a series of fine setae; some of the longitudinal as well as cross veins, especially the branches of Rs and associated cross veins, bear well-defined but short setae.

The closest relatives of this family seem to be the Aspidothoracidae. in which, however, the cross veins, although nearly equally distributed over the wing surface, are much fewer in number and are regular in formation. In the Anchineuridae the cross veins are irregularly

\footnotetext{
${ }^{1}$ This research was supported by National Science Foundation Grant No. NSF G 14099. Manuscript received by the editor December 15, 1962.
} 


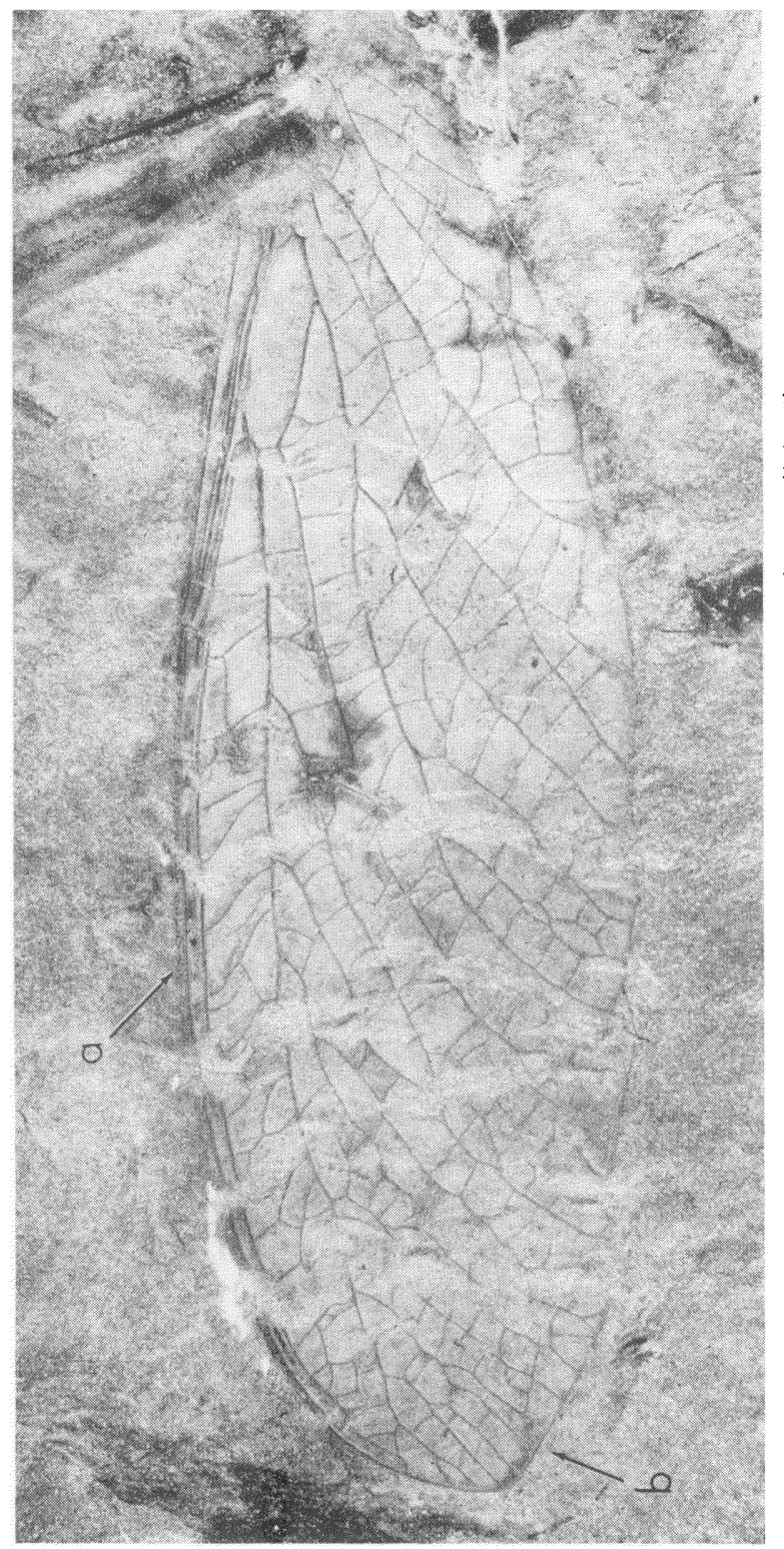


formed, often divided and branched, and in some areas forming a coarse reticulation.

\section{Genus Anchineura, new genus}

$\mathrm{Rs}$ is the most extensively branched longitudinal vein in the wing, having six main branches and numerous terminal ones. $\mathrm{MA}$ and $\mathrm{CuA}$ are unbranched and $\mathrm{MP}$ and $\mathrm{CuP}$ are branched.

Type species: Anchineura hispanica, new species.

Anchineura hispanica, n. sp.

Text figure IA, plates I, 2

Length of wing, $45 \mathrm{~mm}$; maximum width, $\mathrm{I} 3 \mathrm{~mm}$. Costal margin slightly convex, apex broadly rounded, hind margin smoothly curved.
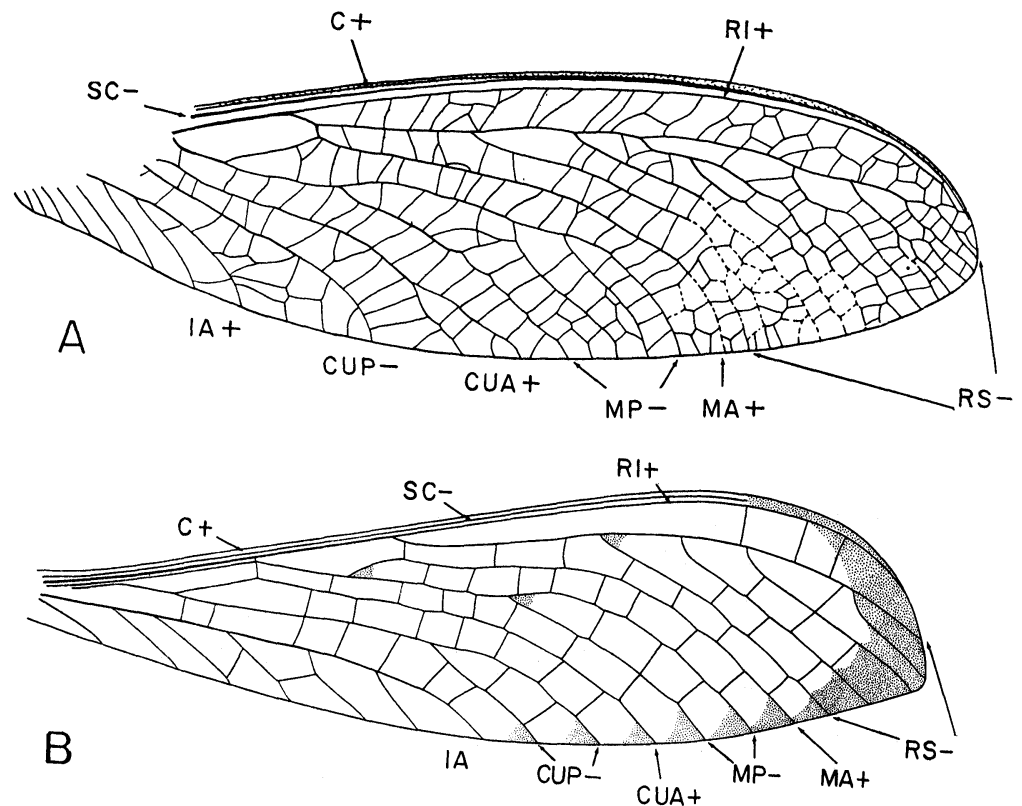

Text figure 1. A, Anchineura hispanica, n.sp. Drawing based on holotype. B, Aspidothorax triangularis Brongniart, from Commentry, France. Original drawing based on specimens in Museum National d'Histoire Naturelle, Paris. $\mathrm{C}$, costa; Sc, subcosta; Rl, radius; Rs, radial sector; MA, anterior media; $\mathrm{MP}$, posterior media ; $\mathrm{CuA}$, anterior cubitus ; $\mathrm{CuP}$, posterior cubitus ; $1 \mathrm{~A}$, anal vein ; +, convex veins; - concave veins.

Rs arising about $\mathrm{I} / 4$ of the wing length from the base, MA arising from $M$ slightly basad of the origin of Rs. MA diverges slightly towards $\mathrm{Rs}$ and is joined to it by a cross vein at that point; MP has 
four terminal branches, one of which arises towards the base of MP, almost directly below the first cross vein joining MA with Rs. Fork of $\mathrm{CuA}$ rather shallow; IA with several marginal branches. Other venational details, including the cross veins, are shown in text figure IA.

Type: specimen no. 97.587, Institut Royal des Sciences Naturelles de Belgique; collected along route from La Magdalena to Barrios de Luna, north of the village of Magdalena, Spain, by Dr. F. Stockmans. The shales in which the insect was collected are of Stephanian age, probably belonging to the upper part of Stephanian B (Wagner, I958, 1959). The type specimen is well-preserved (plate I), except for the basal part of the wing, which is missing; the wing also shows clear signs of having been torn or broken at various places but most of these broken areas are very small and do not interfere with the interpretation of the venational pattern. One of the broken areas is along the anterior margin, not far from the level of the origin of Rs; here the wing margin is broken and the broken ends of the costal margin do not quite meet. That this is an actual break and not a normal part of the wing is clearly shown by the break which continues further towards the center of the wing as far as and slightly beyond Rs. The convexities and concavities of the wing are clearly shown in the fossil, although the wing was probably a very delicate one.

This unusually interesting insect shows, in the wing, some features of both Palaeodictyoptera and Megasecoptera. The cross veins and the main veins, apart from Sc and Rl, could very easily be those of a palaeodictyopterous insect. However, the anterior part of the wing, with Sc and Rl crowded towards the anterior margin, clearly shows megasecopterous affinites. So far as the preserved part of the wing is concerned, the main veins are suggestive of the venation of $A$ spidothorax, from Commentry, France (Stephanian). The relationship between MA and Rs is about the same; unfortunately the specimen of hispanica does not show the basal origin of $\mathrm{CuA}$, although as it appears in the fossil it is very close to the stem of $R$ and could very likely have continued basally parallel and close to $\mathrm{R}$ as it does in Aspidothorax.

The costal area of hispanica is similar to that previously noted in other Megasecoptera. In my account of Actinohymen from the Permian of Texas (Carpenter, 1962), I included a photograph of part of the costal margin of the wing, showing prominent setae or setal bases along the margin. The costal margin of hispanica has similar structures (fig. A, plate 5), especially in the thickened, distal part of the costa. As in Actinohymen, the setae are also present on some of 

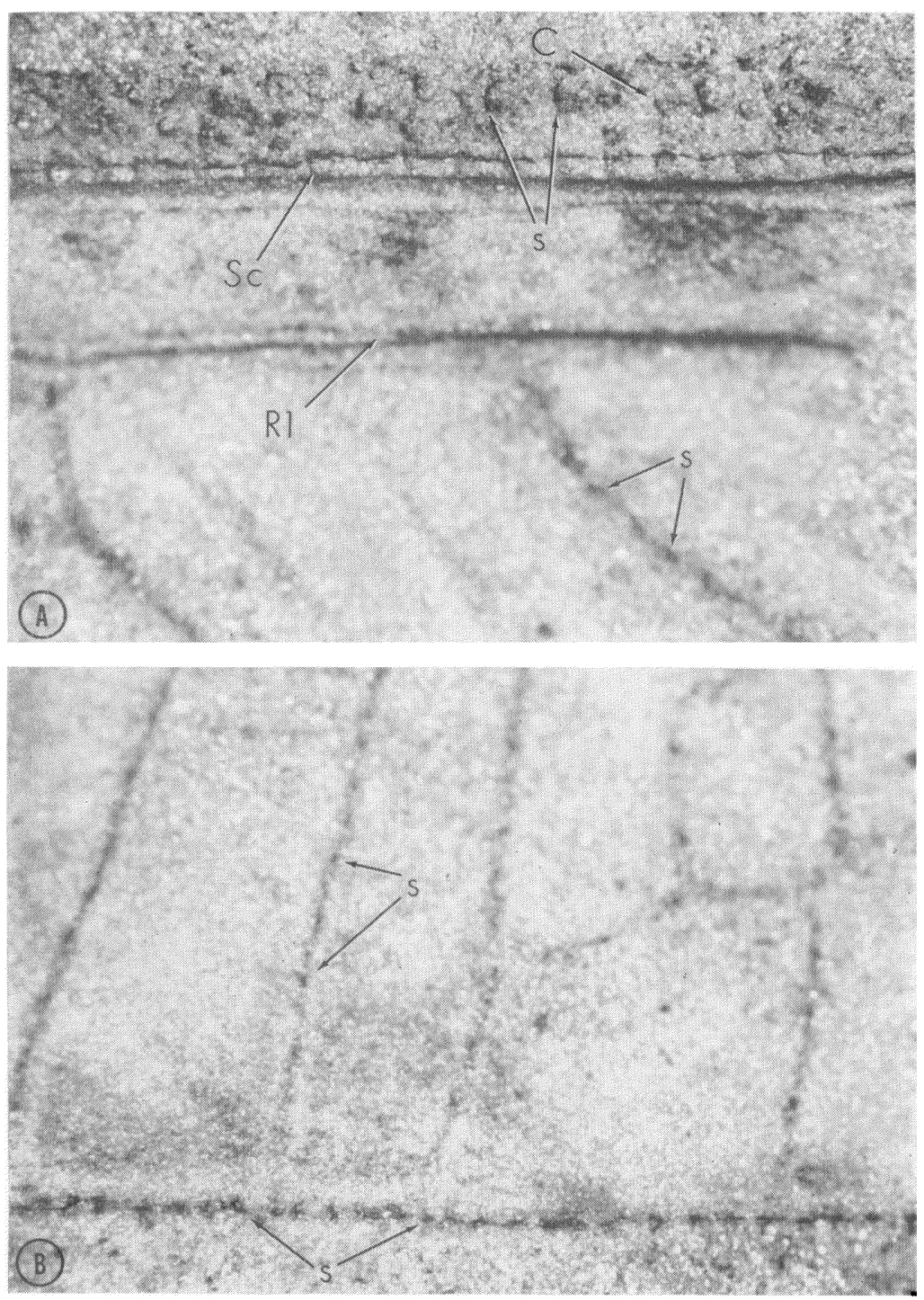

Carpenter - Anchineura 
the main veins and cross veins. Most of them are short, robust spines, like those in certain Odonata (Fraser, 1942). In addition, hispanica has a fringe of short, stout setae extending along the distal and posterior margins of the wing (fig. B, plate 5). I have not previously observed a similar fringe in any Megasecoptera, although a weakly developed one does occur in some Palaeodictyoptera, as Dunbaria.

The presence of numerous irregular cross veins, reminiscent of those of most Palaeodictyoptera, in a wing which is otherwise typically megasecopterous is indicative of the assumed relationship between these two orders. I believe that Anchineura brings the Palaeodictyoptera and Megasecoptera closer together than any previously known fossil has done. This is not to imply that the Anchineuridae are in the direct line of evolution between these orders - much more information about these insects, especially body structures, needs to be known - but Anchineura provides some evidence for a relationship which was previously only assumed.

\section{REFERENCES}

Carpenter, F. M.

1962. A Permian Megasecopteron from Texas. Psyche, 69:37-41.

Fraser, F. C.

1942. A note on the wing-trichiation of the Odonata. Ent. Mo. Mag., 72 : WAGNER, R. H. 235-236.

1958. Pecopteris pseudobucklandi Andrae and its generical affinities. Mededelingen Geologische Stichting (n.s.) no. 12:25-30 (Haarlem).

1955. Flora fóssil y estratigrafía del carbonífero de España N.W. y Portugal N. Estudios Geologicos, Instituto de Investigaciones Geologicas "Lucas Malada", 15:393-420.

\section{Explanation of Plate 5}

Anchineura hispanica, n.sp. A, photograph of part of the costal area of wing (area labeled $a$ on plate 4). B, photograph of part of the hind margin of wing (area labeled $b$ on plate 4). 

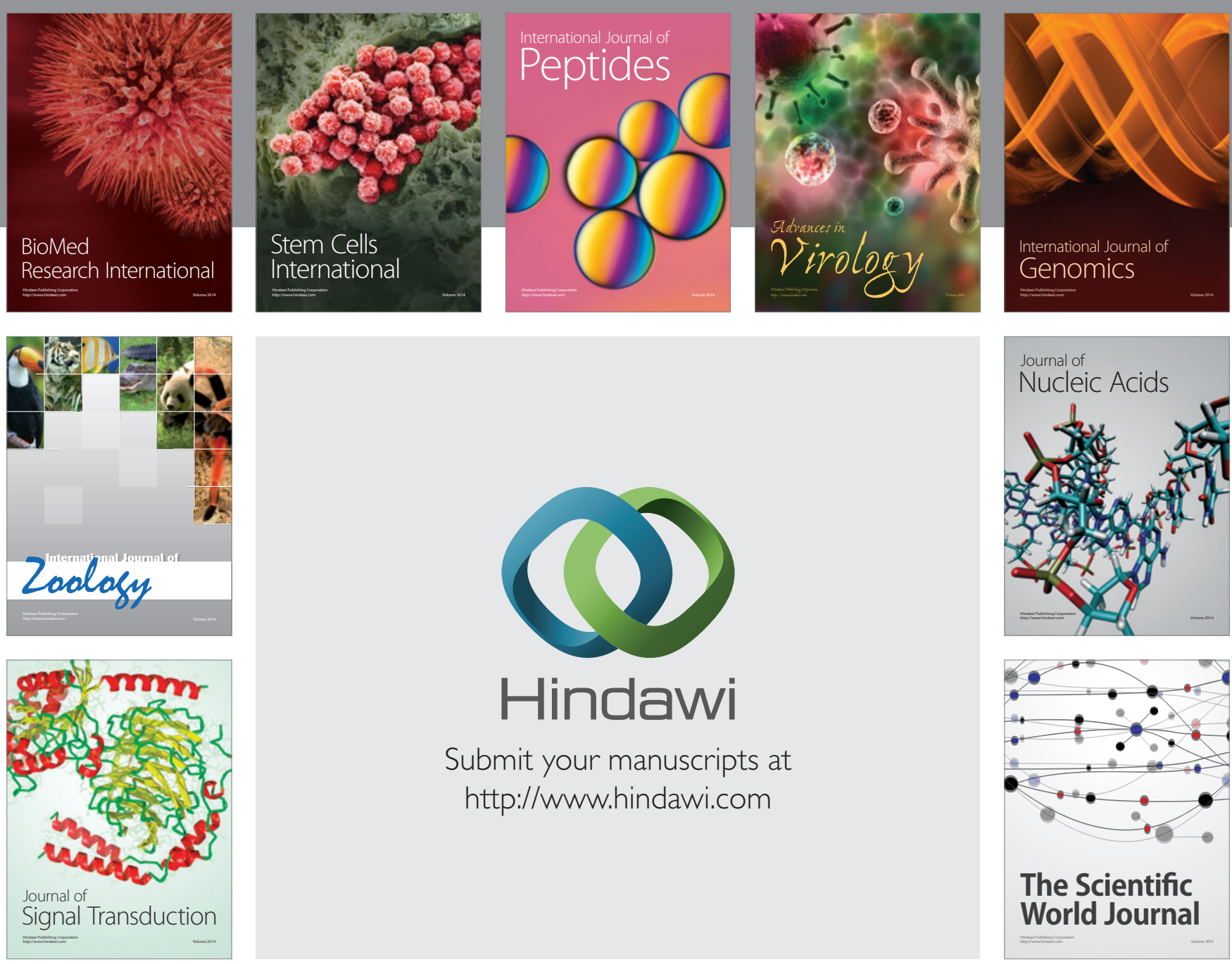

Submit your manuscripts at

http://www.hindawi.com
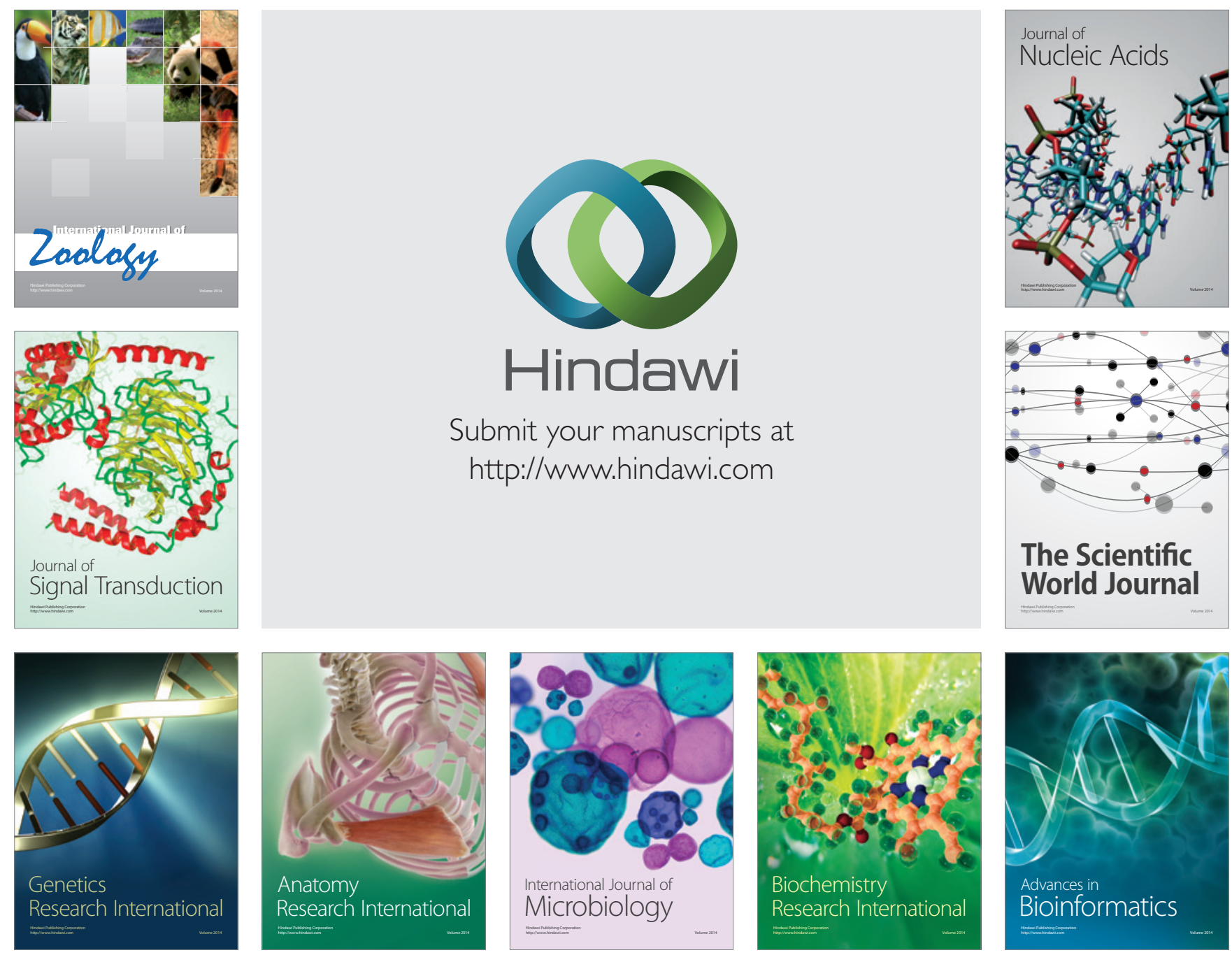

The Scientific World Journal
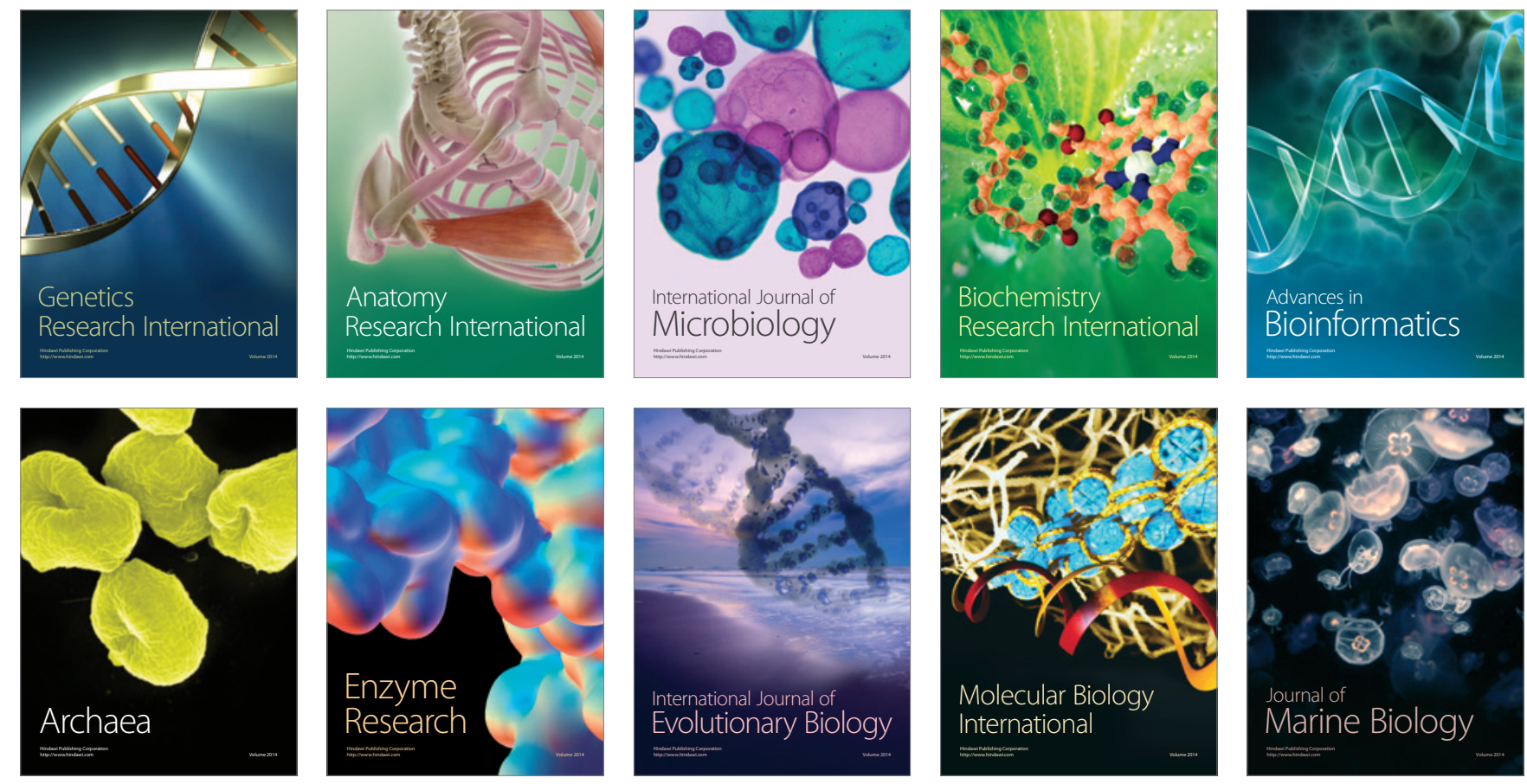